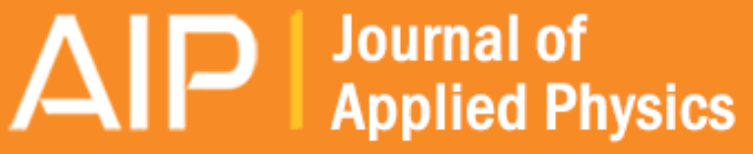

\section{Ultra-thin GaAs single-junction solar cells integrated with a reflective back scattering layer}

Weiquan Yang, Jacob Becker, Shi Liu, Ying-Shen Kuo, Jing-Jing Li, Barbara Landini, Ken Campman, and YongHang Zhang

Citation: Journal of Applied Physics 115, 203105 (2014); doi: 10.1063/1.4878156

View online: http://dx.doi.org/10.1063/1.4878156

View Table of Contents: http://scitation.aip.org/content/aip/journal/jap/115/20?ver=pdfcov

Published by the AIP Publishing

\section{Articles you may be interested in}

$13.2 \%$ efficiency double-hetero structure single-junction InGaAsN solar cells grown by MOVPE

J. Vac. Sci. Technol. A 33, 021205 (2015); 10.1116/1.4906511

Experimental determination of band offsets of NiO-based thin film heterojunctions

J. Appl. Phys. 116, 163108 (2014); 10.1063/1.4900737

The impact of oxygen incorporation during intrinsic $\mathrm{ZnO}$ sputtering on the performance of $\mathrm{Cu}(\mathrm{In}, \mathrm{Ga}) \mathrm{Se} 2$ thin film solar cells

Appl. Phys. Lett. 105, 083906 (2014); 10.1063/1.4894214

Enhancing the efficiency of SnS solar cells via band-offset engineering with a zinc oxysulfide buffer layer Appl. Phys. Lett. 102, 053901 (2013); 10.1063/1.4789855

Analyzing nanotextured transparent conductive oxides for efficient light trapping in silicon thin film solar cells Appl. Phys. Lett. 101, 103903 (2012); 10.1063/1.4750242

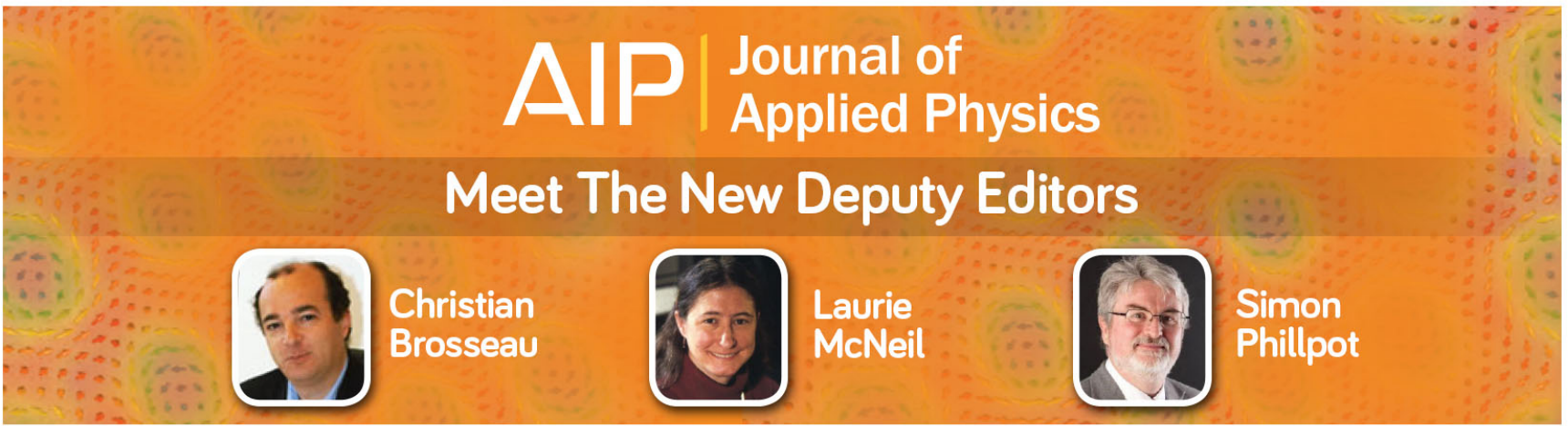




\title{
Ultra-thin GaAs single-junction solar cells integrated with a reflective back scattering layer
}

\author{
Weiquan Yang, ${ }^{1}$ Jacob Becker, ${ }^{1}$ Shi Liu, ${ }^{1}$ Ying-Shen Kuo, ${ }^{1}$ Jing-Jing Li, ${ }^{1}$ Barbara Landini, ${ }^{2}$ \\ Ken Campman, ${ }^{2}$ and Yong-Hang Zhang ${ }^{1}$ \\ ${ }^{1}$ Center for Photonics Innovation and School of Electrical, Computer and Energy Engineering, Arizona State \\ University, Tempe, Arizona 85287, USA \\ ${ }^{2}$ Sumika Electronic Materials, Inc., Phoenix, Arizona 85034, USA
}

(Received 31 October 2013; accepted 5 May 2014; published online 28 May 2014)

\begin{abstract}
This paper reports the proposal, design, and demonstration of ultra-thin GaAs single-junction solar cells integrated with a reflective back scattering layer to optimize light management and minimize non-radiative recombination. According to our recently developed semi-analytical model, this design offers one of the highest potential achievable efficiencies for GaAs solar cells possessing typical non-radiative recombination rates found among commercially available III-V arsenide and phosphide materials. The structure of the demonstrated solar cells consists of an $\mathrm{In}_{0.49} \mathrm{Ga}_{0.51} \mathrm{P} / \mathrm{GaAs} / \mathrm{In}_{0.49} \mathrm{Ga}_{0.51} \mathrm{P}$ double-heterostructure $\mathrm{PN}$ junction with an ultra-thin $300 \mathrm{~nm}$ thick GaAs absorber, combined with a $5 \mu \mathrm{m}$ thick $\mathrm{Al}_{0.52} \mathrm{In}_{0.48} \mathrm{P}$ layer with a textured as-grown surface coated with Au used as a reflective back scattering layer. The final devices were fabricated using a substrate-removal and flip-chip bonding process. Solar cells with a top metal contact coverage of $9.7 \%$, and a $\mathrm{MgF}_{2} / \mathrm{ZnS}$ anti-reflective coating demonstrated open-circuit voltages $\left(V_{o c}\right)$ up to $1.00 \mathrm{~V}$, short-circuit current densities $\left(J_{s c}\right)$ up to $24.5 \mathrm{~mA} / \mathrm{cm}^{2}$, and power conversion efficiencies up to $19.1 \%$; demonstrating the feasibility of this design approach. If a commonly used $2 \%$ metal grid coverage is assumed, the anticipated $J_{s c}$ and conversion efficiency of these devices are expected to reach $26.6 \mathrm{~mA} / \mathrm{cm}^{2}$ and $20.7 \%$, respectively. (C) 2014 AIP Publishing LLC. [http://dx.doi.org/10.1063/1.4878156]
\end{abstract}

\section{INTRODUCTION}

GaAs has the highest demonstrated power conversion efficiency among all types of single-junction solar cells, and is the most promising material for achieving efficiencies that approach the Shockley-Queisser (SQ) limit. Efficiency records of GaAs solar cells have been steadily broken over the past several years. ${ }^{1-3}$ Most of the GaAs solar cells with high efficiencies reported up to now use exceptionally highquality materials for relatively thick absorbers, and planar structures with smooth top surfaces and flat backside mirrors. ${ }^{2-4}$ Different designs to enhance the efficiency have also been proposed and reported, such as the use of planer thin absorbers. ${ }^{5-11}$ In order to increase the efficiency and reduce manufacturing cost by using commonly available materials with routinely achievable quality, it becomes necessary to implement light management structures (e.g., textured surface) ${ }^{12-14}$ to achieve maximum absorption and minimum non-radiative recombination in a thin absorber. Our recently reported theoretical analysis of different optical designs ${ }^{5,6,15,16}$ shows that the use of an ultra-thin (submicron) absorber and a reflective back scattering layer can potentially result in the maximal achievable conversion efficiency for single-junction GaAs solar cells.

In this paper, a solar cell structure consisting of an $\mathrm{In}_{0.49} \mathrm{Ga}_{0.51} \mathrm{P} / \mathrm{GaAs} / \mathrm{In}_{0.49} \mathrm{Ga}_{0.51} \mathrm{P}$ double-heterostructure $\mathrm{PN}$ junction with an ultra-thin GaAs absorber and a textured $\mathrm{Al}_{0.52} \mathrm{In}_{0.48} \mathrm{P} / \mathrm{Au}$ back reflective layer is modeled, designed, and fabricated. Ultra-thin absorbers and textured back reflective layers are chosen to achieve the optimal efficiency using routinely available materials with non-radiative recombination rates similar to those reported in the literature. ${ }^{5,6,17,18}$ The textured back scattering layer, offering light trapping, makes the ultra-thin absorber optically thick but physically thin, and thus optimizes the tradeoff between maximizing absorption of incoming photons and minimizing non-radiative recombination in the absorber. In addition, the textured interface on the backside of the $\mathrm{Al}_{0.52} \mathrm{In}_{0.48} \mathrm{P}$ scattering layer is separated from the GaAs absorber so that the surface-related non-radiative recombination is minimized, while the light scattering is maximized independently. The devices were fabricated using a substrate-removal flip-chip bonding process, and an anti-reflective (AR) coating comprised of a $\mathrm{MgF}_{2} / \mathrm{ZnS}$ double-layer. This work demonstrates the feasibility of the use of ultra-thin absorbers and textured back reflective layers in single-junction solar cells to optimize light management and to minimize non-radiative recombination, and thus achieve high power conversion efficiencies.

\section{DEVICE DESIGN AND MODELING}

The overall device structure is shown in Fig. 1(a). The double-heterostructural GaAs PN junction consists of a $300 \mathrm{~nm}$ GaAs absorber (p-type emitter and n-type base) sandwiched between two $30 \mathrm{~nm}$ doped $\mathrm{In}_{0.49} \mathrm{Ga}_{0.51} \mathrm{P}$ window and back-surface-field (BSF) layers. A textured surface is placed at the backside of the thin-film solar cell to provide optimal scattering of the transmitted light, which is mainly at red and infrared wavelengths. The reflective back scattering 
(a)

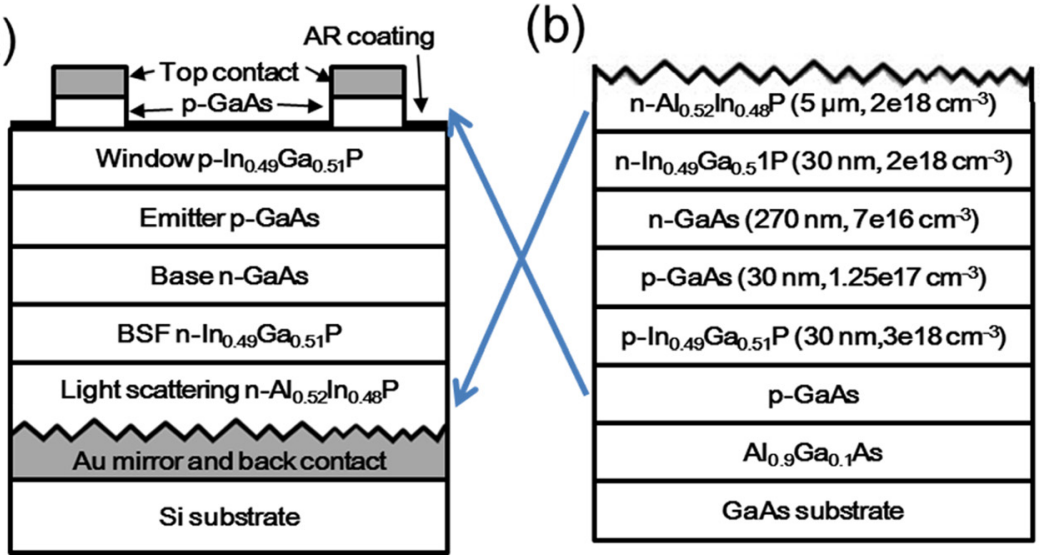

FIG. 1. Schematic layer structure of (a) the finished $\mathrm{In}_{0.49} \mathrm{Ga}_{0.51} \mathrm{P} / \mathrm{GaAs} / \mathrm{In}_{0.49}$ $\mathrm{Ga}_{0.51} \mathrm{P}$ double-heterostructural solar cell with an $\mathrm{Al}_{0.52} \operatorname{In}_{0.48} \mathrm{P}$ layer for reflective back scattering, and (b) as-grown solar cell wafers.

layer underneath the $\operatorname{In}_{0.49} \mathrm{Ga}_{0.51} \mathrm{P}$ BSF layer is a $5 \mu \mathrm{m}$ thick, n-type $\mathrm{Al}_{0.52} \mathrm{In}_{0.48} \mathrm{P}$ layer with a textured surface coated with $\mathrm{Au}$. The entire device is bonded on to a Si carrier substrate using indium. Fig. 1(b) shows the detailed layer structure, including the layer thicknesses and the doping concentrations of the epitaxial wafer prior to device processing.

The optimal thickness of the GaAs absorber is chosen according to simulation using the semi-analytical model ${ }^{5,6}$ that takes into account non-radiative recombination, emittance, and absorptance calculated from the reported absorption coefficients ${ }^{19}$ including the tail below the bandgap wavelength (Urbach tail). Fig. 2(a) shows plots of simulated power conversion efficiencies versus absorber thickness of GaAs single-junction solar cells with ideal textured reflective back surfaces providing Lambertian scattering for given Shockley-Read-Hall (SRH) recombination saturation current densities per unit length $\left(J_{S R H} / d\right)$. The Auger recombination is assumed to be zero, which is reasonable for typical GaAs materials. $J_{S R H} / d$ is proportional to the non-radiative recombination rate per unit volume in the GaAs absorber, and is therefore an effective factor for characterizing the quality of GaAs material. The green dashed curve with $J_{S R H} / d$ equaling $10 \mathrm{~A} / \mathrm{cm}^{2} / \mu \mathrm{m}$ represents the lowest SRH recombination rate reported in the literature for GaAs. ${ }^{5,6}$ A maximum efficiency of $30.9 \%$ is thus potentially achievable with a $230 \mathrm{~nm}$ thick absorber using the proposed structure. The optimal absorber thickness for each structure with a given $J_{S R H} / d$ is the result of a compromise between maximizing the absorption and minimizing the non-radiative recombination loss. The curve of $J_{S R H} / d=0$ represents the case of no non-radiative recombination present; thus, the efficiency approaches the detailed balance limit asymptotically with the absorber thickness approaching infinity. However, as the SRH recombination saturation current density increases with degrading material quality, the maximum achievable efficiency decreases and there exists a decreasing optimal thickness. This trend reveals the advantage of using ultra-thin absorbers when the material has substantial non-radiative recombination loss, such as in the case of solar cells made of thin-film polycrystalline materials.

Utilizing textured surfaces for light management in GaAs-based single- or multi-junction solar cells is challenging. This is mainly due to the fact that the absorbers in those cells usually have large absorption coefficients and are, therefore, very thin with a typical thickness of only a few microns. These thin layers make it difficult to texture the absorber surfaces. Texturing becomes even more difficult for ultra-thin GaAs absorbers on the order of a few hundred nanometers. Furthermore, textured absorbers have large surface or interface areas and thus result in significantly increased non-radiative surface/interface recombination. The solution proposed here is to integrate the solar cell with a wide-bandgap back scattering layer coated with a reflective mirror. The key advantage of this design is that the textured surface and the absorber/BSF interface are separated. The textures are fabricated on the thick wide-bandgap light scattering layer, and the surfaces of the ultra-thin GaAs absorber remain planar. Therefore, the non-radiative interface recombination of the GaAs absorber will not be increased. It is essential that the material used for the back scattering layer has a large bandgap to minimize the parasitic optical absorption of the transmitted light, as well as be lattice-matched to GaAs to minimize the number of misfit dislocations formed during epitaxial growth. The simulated power conversion efficiencies of GaAs single-junction solar cells integrated with $5 \mu \mathrm{m}$ thick reflective back scattering layers comprised of several different III-V materials $\left(\mathrm{Al}_{0.50} \mathrm{In}_{0.50} \mathrm{P}\right.$, $\mathrm{Al}_{0.80} \mathrm{Ga}_{0.20} \mathrm{As}, \mathrm{Al}_{0.59} \mathrm{Ga}_{0.41} \mathrm{As}$, and $\left.\mathrm{Ga}_{0.50} \mathrm{In}_{0.50} \mathrm{P}\right)$ are plotted versus absorber thickness in Fig. 2(b). The reported absorption coefficients $\mathrm{s}^{20-22}$ are used for the various back scattering materials. The best reported value of $J_{S R H} / d=10 \mathrm{~A} / \mathrm{cm}^{2} / \mu \mathrm{m}$ and a typical Auger recombination saturation current density per unit length $J_{\text {Auger }} / d=120 \mathrm{~A} / \mathrm{cm}^{2} / \mu \mathrm{m}$ for GaAs are used. ${ }^{6}$ Ideal AR coatings with no reflection loss and no top contact grid coverage are also assumed here. Note that the choice of $5 \mu \mathrm{m}$ as the back scattering layer thickness in the modeling is due to growth considerations, which will be discussed below. The figure clearly indicates the benefits of using textured $\mathrm{Al}_{0.50} \mathrm{In}_{0.50} \mathrm{P}$ layer for back scattering, as it offers the largest efficiency among the four candidates due to its widest bandgap and correspondingly low parasitic absorption of the transmitted light. From the simulation, the optimal thickness of the GaAs absorber with the $\mathrm{Al}_{0.50} \mathrm{In}_{0.50} \mathrm{P}$ back scattering layer is $280 \mathrm{~nm}$. It is noted here that the model assumes ideal Lambertian back scattering. A slightly thicker GaAs absorber $(300 \mathrm{~nm})$ is chosen in this work to compensate for the non-ideal scattering typically found in practical devices.

A $\mathrm{MgF}_{2} / \mathrm{ZnS}$ double-layer AR coating is designed and optimized by minimizing the front surface reflectance 

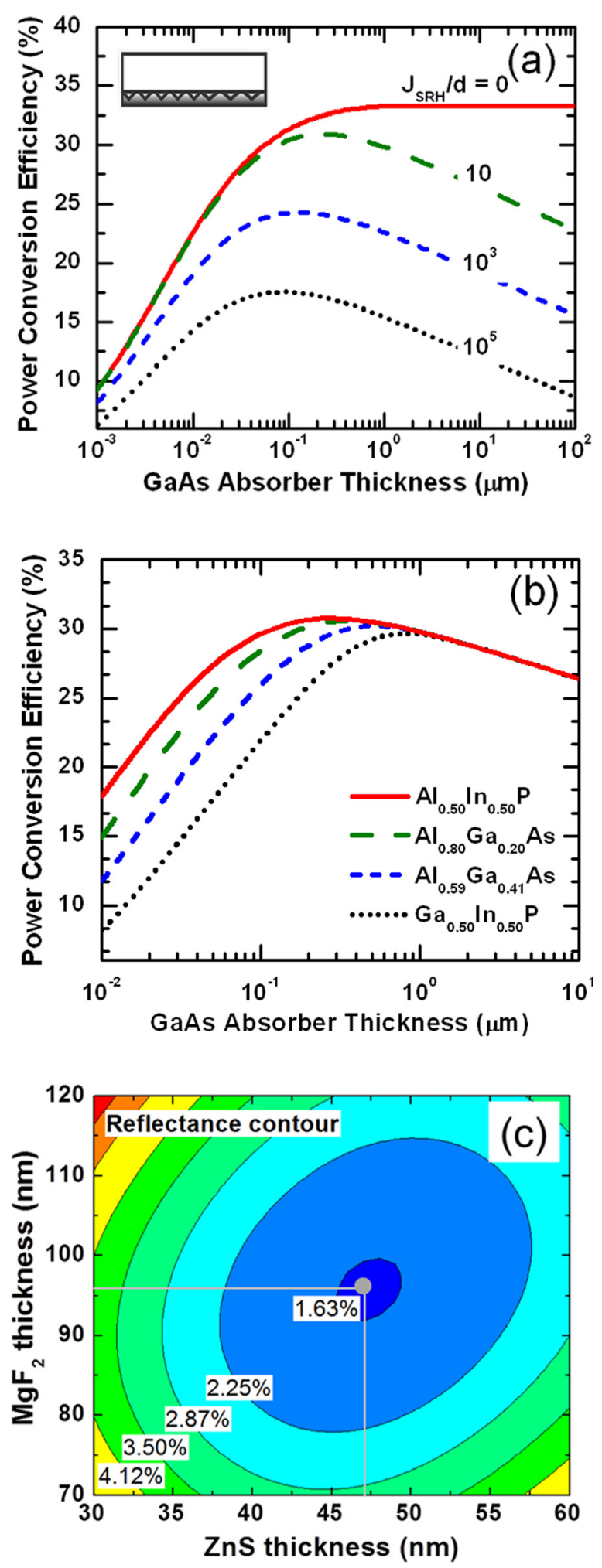

FIG. 2. Simulated power conversion efficiency of GaAs single-junction solar cells (a) versus GaAs absorber thickness for various normalized SRH non-radiative recombination saturation current densities per unit length $\mathrm{J}_{\mathrm{SRH}} / \mathrm{d}\left(\mathrm{A} / \mathrm{cm}^{2} / \mu \mathrm{m}\right)$; (b) versus GaAs absorber thickness for four different III-V materials lattice-matched to GaAs integrated as the back scattering layer; (c) simulated reflectance contour $\mathrm{R}$ total for $\mathrm{MgF}_{2} / \mathrm{ZnS}$ double-layer AR coating on a GaAs solar cell.

calculated by the transfer matrix method. Note that since the thickness of the GaAs absorber is only $300 \mathrm{~nm}$, it is necessary to take into account the GaAs ultra-thin absorber,
$\mathrm{In}_{0.49} \mathrm{Ga}_{0.51} \mathrm{P}$ window, and $\mathrm{BSF}$ layers in the transfer matrix calculation. Once each reflection spectrum is calculated using published complex refractive indices, ${ }^{19,20}$ it is weighted against the solar spectrum and then integrated below the GaAs bandgap wavelength $(280 \mathrm{~nm}-870 \mathrm{~nm})$ to produce a total reflectance for every thickness combination of the $\mathrm{MgF}_{2} / \mathrm{ZnS}$ double-layer, as shown by the equation below

$$
R_{\text {total }}=\frac{\int_{280 \mathrm{~nm}}^{870 \mathrm{~nm}} R(\lambda) \cdot N_{\text {sun }}(\lambda) d \lambda}{\int_{280 \mathrm{~nm}}^{870 \mathrm{~nm}} N_{\text {sun }}(\lambda) d \lambda},
$$

where $R_{\text {total }}$ is the total reflectance of the AR coating, $R(\lambda)$ is the wavelength-dependent reflectance of the AR coating, and $N_{\text {sun }}(\lambda)$ is the photon flux per wavelength from solar radiation. Fig. 2(c) depicts the simulated total reflectance $\left(R_{\text {total }}\right)$ contours versus variable $\mathrm{MgF}_{2}$ and $\mathrm{ZnS}$ thicknesses. The optimal design ( $96 \mathrm{~nm} \mathrm{MgF}_{2} / 47 \mathrm{~nm} \mathrm{ZnS}$ pair) is denoted in the figure by the grey dot in the approximate center, where a minimum $R_{\text {total }}$ of $1.60 \%$ is achieved.

\section{MATERIAL GROWTH AND DEVICE FABRICATION}

The solar cell structures shown in Fig. 1(b) were grown using MOCVD at Sumika Inc., a commercial epi foundry. The double-heterostructural $\mathrm{n}-\mathrm{In}_{0.49} \mathrm{Ga}_{0.51} \mathrm{P} / \mathrm{n}-\mathrm{GaAs} / \mathrm{p}-\mathrm{GaAs} /$ p- $\mathrm{In}_{0.49} \mathrm{Ga}_{0.51} \mathrm{P}$ PN junction was deposited on an $\mathrm{Al}_{0.9} \mathrm{Ga}_{0.1} \mathrm{As}$ sacrificial layer grown on a GaAs substrate. The p-GaAs and $\mathrm{n}-\mathrm{GaAs}$ layers have thicknesses of $30 \mathrm{~nm}$ and $270 \mathrm{~nm}$, and corresponding doping concentrations of $1.25 \times 10^{17} \mathrm{~cm}^{-3}$ and $7 \times 10^{16} \mathrm{~cm}^{-3}$, respectively. The window layer and BSF layer are $\mathrm{In}_{0.49} \mathrm{Ga}_{0.51} \mathrm{P}$ offering a high quality interface with GaAs.

A $5 \mu \mathrm{m}$ thick n-type $\mathrm{Al}_{0.52} \operatorname{In}_{0.48} \mathrm{P}$ layer with a textured surface is grown on top of the second $\operatorname{In}_{0.49} \mathrm{Ga}_{0.51} \mathrm{P}$ layer. The cone-shaped textures on the surface of the $\mathrm{Al}_{0.52} \mathrm{In}_{0.48} \mathrm{P}$ layer were developed during the growth; hence, no additional processing was required to produce the textured surface for light scattering. Several calibration growths of $\mathrm{Al}_{0.52} \mathrm{In}_{0.48} \mathrm{P}$ layers with different thicknesses were carried out to investigate the correlation between texture distribution and the $\mathrm{Al}_{0.52} \mathrm{In}_{0.48} \mathrm{P}$ thickness. Figs. 3(a)-3(c) show the cross-sectional SEM images of the $\mathrm{Al}_{0.52} \mathrm{In}_{0.48} \mathrm{P}$ surface with thicknesses of $1 \mu \mathrm{m}, 3.8 \mu \mathrm{m}$, and $5 \mu \mathrm{m}$. When the $\mathrm{Al}_{0.52} \mathrm{In}_{0.48} \mathrm{P}$ thickness was only $1 \mu \mathrm{m}$, most of the surface was smooth and sparse discrete cone textures were formed. The $3.8 \mu \mathrm{m} \mathrm{Al}_{0.52} \mathrm{In}_{0.48} \mathrm{P}$ layer showed denser surface textures. However, most of the textures were still discrete, with only a few features beginning to connect with each other. For the $5 \mu \mathrm{m} \mathrm{Al}{ }_{0.52} \operatorname{In}_{0.48} \mathrm{P}$ layer, all of the texture features are connected with each other to cover the entire surface. Therefore, $5 \mu \mathrm{m}$ was chosen as the thickness of the $\mathrm{Al}_{0.52} \mathrm{In}_{0.48} \mathrm{P}$ back scattering layer. A zoom-in cross-sectional view of a texture cone with a height of $1 \mu \mathrm{m}$ and a bottom diameter of around $5 \mu \mathrm{m}$ is shown in Fig. 3(c) inset. The scale in the vertical axis is the same as that in the horizontal axis. Fig. 3(d) shows a top-view microscope image of the 


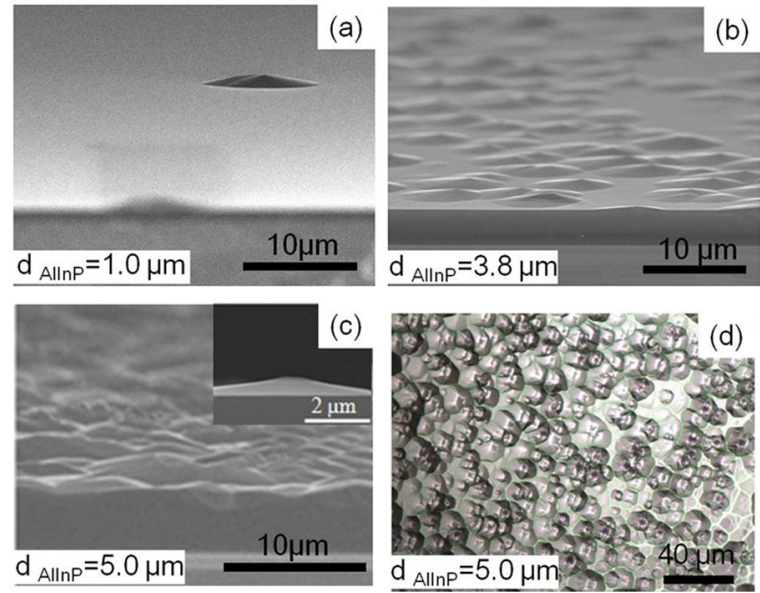

FIG. 3. Cross-section SEM images of as-grown $\mathrm{Al}_{0.52} \mathrm{In}_{0.48} \mathrm{P}$ surfaces when the $\mathrm{Al}_{0.52} \mathrm{In}_{0.48} \mathrm{P}$ thickness is (a) $1 \mu \mathrm{m}$, (b) $3.8 \mu \mathrm{m}$, and (c) $5 \mu \mathrm{m}$; (d) top-view microscopic images of as-grown $\mathrm{Al}_{0.52} \mathrm{In}_{0.48} \mathrm{P}$ surface when the $\mathrm{Al}_{0.52} \mathrm{In}_{0.48} \mathrm{P}$ thickness is $5 \mu \mathrm{m}$. Inset in (c) gives a zoomed-in SEM image of a typical cone texture (height $\sim 1 \mu \mathrm{m}$, diameter $\sim 5 \mu \mathrm{m}$ ).

as-grown $\mathrm{Al}_{0.52} \mathrm{In}_{0.48} \mathrm{P}$ surface with high-density cone features.

The device processing begins with the as-grown solar cell structures shown in Fig. 4(a). The initial stage was to prepare the back contact and mirror prior to the flip-chip mounting of the device. The commonly used alloyed metal contact (e.g., $\mathrm{Ni} / \mathrm{Ge} / \mathrm{Au} / \mathrm{Ti} / \mathrm{Au}$ ) for $\mathrm{n}-\mathrm{GaAs}$ has excellent contact conductance but poor reflectance. Conversely, a pure $\mathrm{Au}$ layer has excellent reflectance but poor contact conductance. Therefore, in order to maximize the reflectivity of the back mirror and minimize the contact resistance of the back contact, point contacts $(\mathrm{Ni} / \mathrm{Ge} / \mathrm{Au} / \mathrm{Ti} / \mathrm{Au})$ were used as shown in Fig. 4(b). Each point contact has a size of $10 \times 10 \mu \mathrm{m}^{2}$ with a distance of $200 \mu \mathrm{m}$ between adjacent points. Thus, the total area of the point contacts accounts for only $0.25 \%$ of the back surface. The point contacts were made using a standard photolithography, e-beam deposition, and lift-off process. The sample was then annealed using a rapid thermal annealing process at $425^{\circ} \mathrm{C}$ to form ohmic contacts. The remaining GaAs back contact layer was then removed using a citric acid solution revealing the $\mathrm{Al}_{0.52} \mathrm{In}_{0.48} \mathrm{P}$ back scattering layer. $\mathrm{A} \mathrm{Au}$ film was then deposited on the textured $\mathrm{Al}_{0.52} \mathrm{In}_{0.48} \mathrm{P}$ layer to function as the mirror. No annealing process was used after the mirror deposition in order to maintain a high reflectivity at that surface. In addition to the initial Au layer, a $\mathrm{Cr}$ layer was also deposited as a diffusion barrier to prevent degradation of the mirror quality from the diffusion of indium used in subsequent steps. A second Au layer was then deposited to function as a wetting layer to better adhere to the indium. Fig. 4(c) shows, schematically, the mirror deposited on the textured $\mathrm{Al}_{0.52} \mathrm{In}_{0.48} \mathrm{P}$ layer along with the point contacts. Indium was used as the bonding medium to secure the GaAs wafer to the Si carrier wafer. A Ti/Au film deposited onto the Si carrier wafer using E-beam evaporation prior to the bonding process acts as a wetting layer for better adhesion to the indium, and also as the back probing pad of the solar cells during the final measurement. Indium shot was melted across the surface of the Si wafer using a hot plate at $210^{\circ} \mathrm{C}$, and the $\mathrm{GaAs}$ wafer was mounted on the indium, mirror side down. Fig. 4(d) shows the structure after the sample was bonded to the $\mathrm{Si}$ carrier wafer.

The GaAs substrate was then removed through a chemical-etching process over a period of approximately $3 \mathrm{~h}$ using an $\mathrm{NH}_{4} \mathrm{OH} / \mathrm{H}_{2} \mathrm{O}_{2}$ solution. The $\mathrm{Al}_{0.9} \mathrm{Ga}_{0.1}$ As etch-stop layer prevented the absorber from being removed. This $\mathrm{Al}_{0.9} \mathrm{Ga}_{0.1} \mathrm{As}$ etch-stop layer was then removed using an $\mathrm{HF} / \mathrm{H}_{2} \mathrm{O}$ solution as shown in Fig. 4(e). The top Ti/Pt/Au contact grids were deposited using a photolithography, E-beam evaporation, and lift-off process. The exposed GaAs contact layer was then removed using a citric acid etchant to expose the $\operatorname{In}_{0.49} \mathrm{Ga}_{0.51} \mathrm{P}$ window layer underneath, as shown in Fig. 4(f). The individual devices were isolated using chemical etching between the mesas, as shown in Fig. 4(g), with $\mathrm{HNO}_{4} / \mathrm{HCl} / \mathrm{H}_{2} \mathrm{O}$ used as the etching solution. The final cell geometries are $0.3 \mathrm{~mm} \times 0.3 \mathrm{~mm}, 0.6 \mathrm{~mm} \times 0.6 \mathrm{~mm}$, and $1 \mathrm{~mm} \times 1 \mathrm{~mm}$. The thickness-optimized $\mathrm{MgF}_{2} / \mathrm{ZnS}$ layers for the AR coating were then deposited using a standard

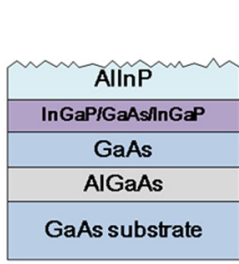

(a)

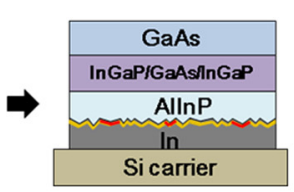

(e)

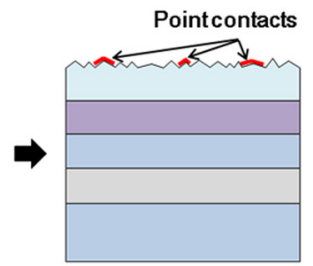

(b)

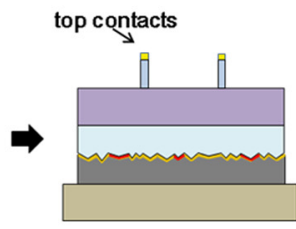

(f)

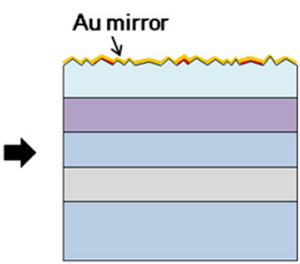

(c)

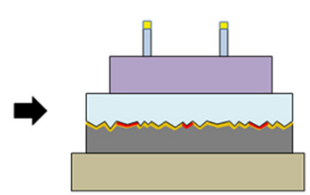

(g)

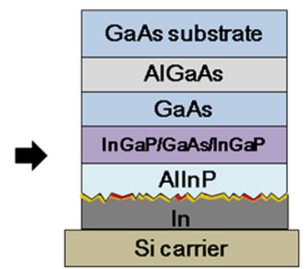

(d)

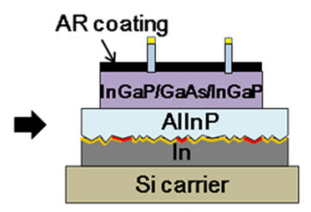

(h)

FIG. 4. Schematic flow of the device growth and fabrication processes: (a) MOCVD growth of the double-heterostructure PN junction device with an $\mathrm{A}_{0.52} \mathrm{In}_{0.48} \mathrm{P}$ light scattering layer on a GaAs substrate; (b) metals deposition for point contacts; (c) deposition of Au mirror; (d) flip-chip bonding to a Si carrier

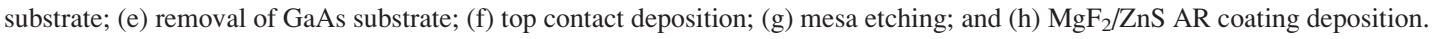




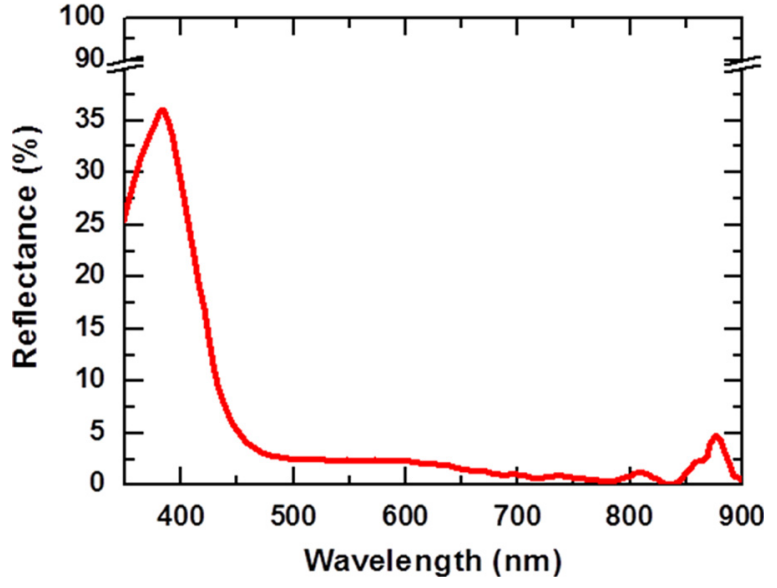

FIG. 5. Measured reflectance of a $97 \mathrm{~nm} \mathrm{MgF}_{2} / 68 \mathrm{~nm} \mathrm{ZnS}$ AR coating on a blank GaAs calibration wafer.

photolithography, thermal evaporation, and lift-off process. Fig. 4(h) shows the final device schematic including the AR coating ready for test.

A custom built thermal evaporation tool was used for the AR coating deposition. During deposition, a blank GaAs calibration wafer was placed alongside the actual devices to permit straightforward measurement of the AR coating thickness and reflectance. The $\mathrm{MgF}_{2}$ and $\mathrm{ZnS}$ thicknesses on the calibration wafer were measured to be $97 \mathrm{~nm}$ and $68 \mathrm{~nm}$ by Filmetrics F-40 reflectance measurement, respectively. The reflectance curve of the calibration wafer is shown in Fig. 5. This reflectance curve is then weighted against the solar spectrum and integrated below the GaAs bandgap wavelength as described above. A total reflectance $\left(R_{\text {total }}\right)$ of $3.77 \%$ was obtained for this $\mathrm{MgF}_{2} / \mathrm{ZnS}$ bilayer stack. Due to the limitation of the custom tool used for AR coating deposition, there is a large spatial variation of the deposited film thickness. As the calibration wafer and the solar cell devices are at different locations, the final AR coating thicknesses on the solar cell samples may be slightly different from that of the calibration wafer.

\section{DEVICE CHARACTERIZATION AND ANALYSIS}

The current-voltage (I-V) characteristics of the processed solar cell devices were measured using an Oriel ClassA solar simulator (AM $1.5 \mathrm{G}, 0.1 \mathrm{~W} / \mathrm{cm}^{2}$ ) and a Keithley 2400 source meter. The spectral reflectance measurements of the $\mathrm{MgF}_{2} / \mathrm{ZnS}$ AR coating were carried out at normal incidence using a Perkin Elmer Lambda $18 \mathrm{UV}-\mathrm{Vis}$ spectrometer. The external quantum efficiencies (EQE) of the devices were measured at room temperature using a Newport QE/IPCE measurement setup.

Because the devices were not thermally annealed after the front-contact deposition to avoid degradation of the $\mathrm{Au}$ mirror and the melting of the indium, the device structure utilizes a $6 \mathrm{~nm}$ highly doped $\left(1 \times 10^{19} \mathrm{~cm}^{-3}\right) \mathrm{p}^{+}$-GaAs layer on the $200 \mathrm{~nm}$ p-GaAs as a non-alloyed ohmic contact layer. The contact resistance of the top p-contact grids was characterized using the transfer length method (TLM). The I-V characteristics measured between two adjacent electrodes with different spacing $(20 \mu \mathrm{m}, 40 \mu \mathrm{m}, 60 \mu \mathrm{m}, 80 \mu \mathrm{m}$, and

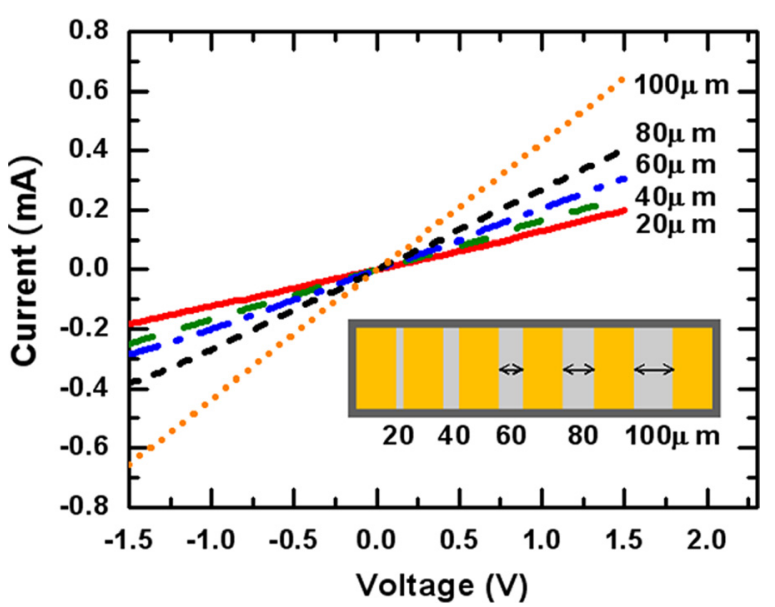

FIG. 6. Current-voltage curves of TLM contacts with pad spacing distances of $20,40,60,80$, and $100 \mu \mathrm{m}$.

$100 \mu \mathrm{m})$ are shown in Fig. 6. The linear I-V curves reveal that the top metal p-GaAs contacts are ohmic with a specific contact resistivity of $6.51 \times 10^{-3} \Omega \cdot \mathrm{cm}^{2}$.

The finished devices have various areas ranging from $0.09 \mathrm{~mm}^{2}$ to $1 \mathrm{~mm}^{2}$ as shown in the optical micrograph (Fig. 7). Devices with an area of $0.09 \mathrm{~mm}^{2}$ and a $9.7 \%$ top contact grid coverage were characterized at room temperature under 1 sun AM 1.5G solar spectrum. A typical I-V plot of the 0.09 $\mathrm{mm}^{2}$ solar cell is shown in Fig. 8. Short-circuit current densities $\left(J_{s c}\right)$ as high as $24.5 \mathrm{~mA} / \mathrm{cm}^{2}$, open-circuit voltages $\left(V_{o c}\right)$ up to $1.00 \mathrm{~V}$, fill factors $(F F)$ of $77.8 \%$, and power conversion efficiencies $(\eta)$ up to $19.1 \%$ were attained. The measured performance is compared with the best achievable performance, both of which are summarized in Table I. The best achievable performance is modeled based on the assumptions of Lambertian scattering on the back side of the cell, a back mirror with $100 \%$ reflectivity, an AR coating with $2 \%$ reflectance, a $2 \%$ top contact grid coverage, the best material quality with the longest minority carrier lifetime published, and no series or shunt resistance.

The demonstrated GaAs single-junction solar cells with a $300 \mathrm{~nm}$ absorber have a maximum achievable $J_{s c}$ of

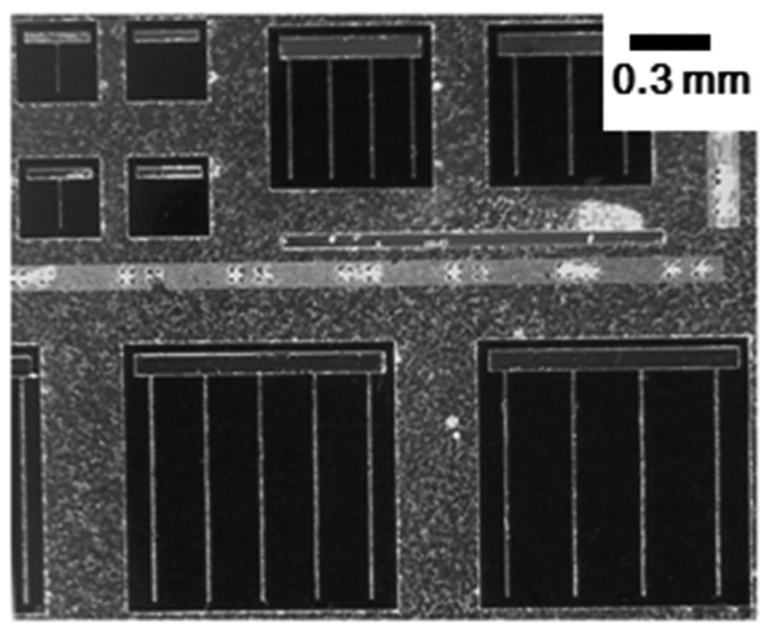

FIG. 7. Optical micrograph of fabricated solar cells possessing different areas. 


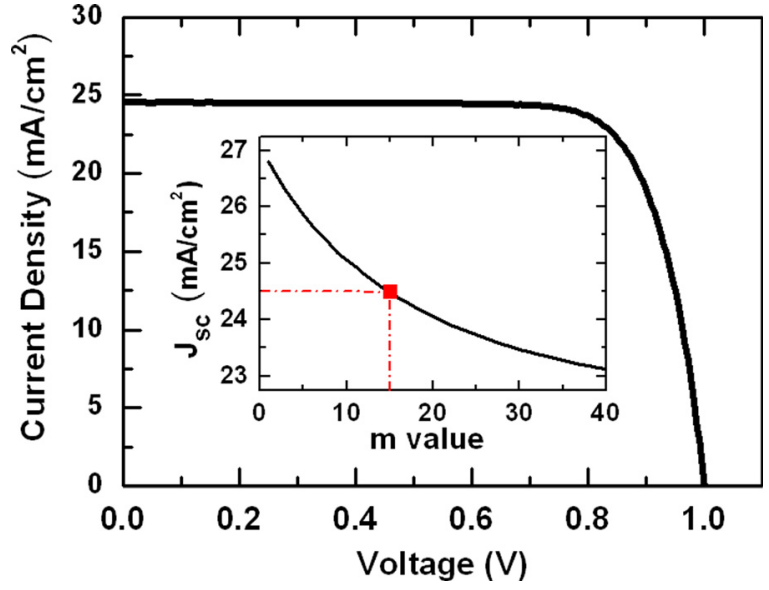

FIG. 8. Measured room-temperature I-V characteristics of the GaAs solar cells under 1 sun (AM 1.5G). Inset: calculated short-circuit current density $\left(\mathrm{J}_{\mathrm{sc}}\right)$ as a function of Phong exponent $(\mathrm{m})$.

$30.7 \mathrm{~mA} / \mathrm{cm}^{2}$. The best device with a $300 \mathrm{~nm}$ absorber tested has a measured $J_{s c}$ of $24.5 \mathrm{~mA} / \mathrm{cm}^{2}$. The causes of this discrepancy from the maximum achievable $J_{s c}$ are: (1) the optical scattering in the actual devices is not as efficient as Lambertian scattering; (2) the Au mirror has less than $100 \%$ reflectivity; (3) the AR coating has a larger reflectance $(3.8 \%)$ than that used in the model $(2 \%)$; and (4) the metal grid coverage $(9.7 \%)$ is much higher than that used in the model (2\%). If a $2 \%$ metal grid shadowing is assumed as in conventional devices and all other factors remain the same, the $J_{s c}$ and power conversion efficiency of these actual devices could reach $26.6 \mathrm{~mA} / \mathrm{cm}^{2}$ and $20.7 \%$, respectively. The resulting $4.1 \mathrm{~mA} / \mathrm{cm}^{2}$ difference between the projected and maximum achievable $J_{s c}$ is due in part to non-ideal scattering. The impacts of non-ideal scattering are addressed as below.

Phong's distribution can be used to describe non-ideal scattering deviating from Lambertian scattering. ${ }^{23}$ The angular light intensity is proportional to $\cos ^{m}(\theta)$, where $\theta$ is the angle between the scattered light and the surface normal, and the Phong exponent $(m)$ can be used to describe the angular intensity distribution. Note here that $m=1$ corresponds to the Lambertian distribution, and higher values of $m$ result in narrower angular intensity distributions. The calculated $J_{s c}$ as a function of $m$ value is shown in Fig. 8 inset. The calculation assumes a reflectivity of $95 \%$ for the back $\mathrm{Al}_{0.52} \mathrm{In}_{0.48} \mathrm{P} / \mathrm{Au}$ mirror, a metal grid shadow area of $9.7 \%$, and a front surface reflection loss of $3.8 \%$. The value of $95 \%$ is chosen as an approximation of the reflectivity of the rough $\mathrm{Al}_{0.52} \mathrm{In}_{0.48} \mathrm{P} / \mathrm{Au}$ mirror based on the Au reflectivity spectrum and its angular distribution. The calculation results indicate that the $\mathrm{Al}_{0.52} \mathrm{In}_{0.48} \mathrm{P} / \mathrm{Au}$ reflectivity averaged against the Lambertian distribution $(m=1)$ at the GaAs band edge

TABLE I. Comparison between the measured and modeled best achievable device performance of $300 \mathrm{~nm}$ GaAs single-junction solar cell.

\begin{tabular}{lcccc}
\hline \hline & $V_{o c}(\mathrm{~V})$ & $J_{s c}\left(\mathrm{~mA} / \mathrm{cm}^{2}\right)$ & $F F(\%)$ & $\eta(\%)$ \\
\hline Modeled best achievable & 1.13 & 30.7 & 85.4 & 29.5 \\
Measured & 1.00 & 24.5 & 77.8 & 19.1 \\
\hline \hline
\end{tabular}

wavelength $(870 \mathrm{~nm})$ is $94.8 \%$, while the value for the narrowest Phong's distribution $(m=\infty)$ is $94.4 \%$. Fig. 8 inset shows that $J_{s c}$ decreases from $\sim 27 \mathrm{~mA} / \mathrm{cm}^{2}$ to $\sim 23 \mathrm{~mA} / \mathrm{cm}^{2}$ as the $m$ value increases from 1 to 40 , which represents that the scattering gradually deviates from a Lambertian distribution to a Phong's distribution. The $m$ value of the Phong's distribution in our device is determined to be 15 by fitting the modeled $J_{s c}$ to the experimental results.

The over $0.1 \mathrm{~V}$ difference between the measured and the theoretically predicted, best achievable $V_{o c}$ could be partly due to SRH and interface/surface recombination losses. The impact of interface/surface recombination becomes relatively more important for such a thin absorber. The current low $F F$ value of $77.8 \%$ is mainly due to the series resistance. A specific series resistivity of $0.5 \Omega \cdot \mathrm{cm}^{2}$ is determined by fitting the deviation of the dark I-V curve from the ideal diode equation at a positive bias voltage of $1.5 \mathrm{~V}$. Poor current spreading in the devices with ultra-thin absorber and window layers, sparse back point contacts, as well as non-annealed top contact grids all contribute to this relatively high series resistance. The $F F$ can be potentially improved by using our recently proposed conductive AR coating. ${ }^{24}$

Fig. 9 shows the EQE of the measured solar cell. The EQE increases from $80 \%$ at $400 \mathrm{~nm}$ to $90 \%$ at $470 \mathrm{~nm}$. Note that the light at a wavelength near $400 \mathrm{~nm}$ is mainly absorbed by the $\operatorname{In}_{0.49} \mathrm{Ga}_{0.51} \mathrm{P}$ window layer. The high EQE near $400 \mathrm{~nm}$ indicates that the highly efficient extraction of those photo-generated carriers in the window layer is due to the shallow PN junction of the ultra-thin absorber and the extension of the depletion region into the window layer. The maximum value of the EQE is only $~ 90 \%$ mainly due to the fact that the top grid has a shadow area of $9.7 \%$. The EQE is close to $65 \%$ at $800 \mathrm{~nm}$ and above $40 \%$ at the bandgap wavelength of $870 \mathrm{~nm}$. The light absorption at $800 \mathrm{~nm}$ is calculated to be $\sim 54 \%$ for devices with specular reflective back surfaces without light scattering. These calculations assume shadow area of $9.7 \%$, a reflectivity of $95 \%$ for the back $\mathrm{Al}_{0.52} \mathrm{In}_{0.48} \mathrm{P} / \mathrm{Au}$ mirror, and a reflectance of $2 \%$ at $800 \mathrm{~nm}$ for AR coating. The $11 \%$ increase in the measured EQE compared with the calculated specular light absorption at

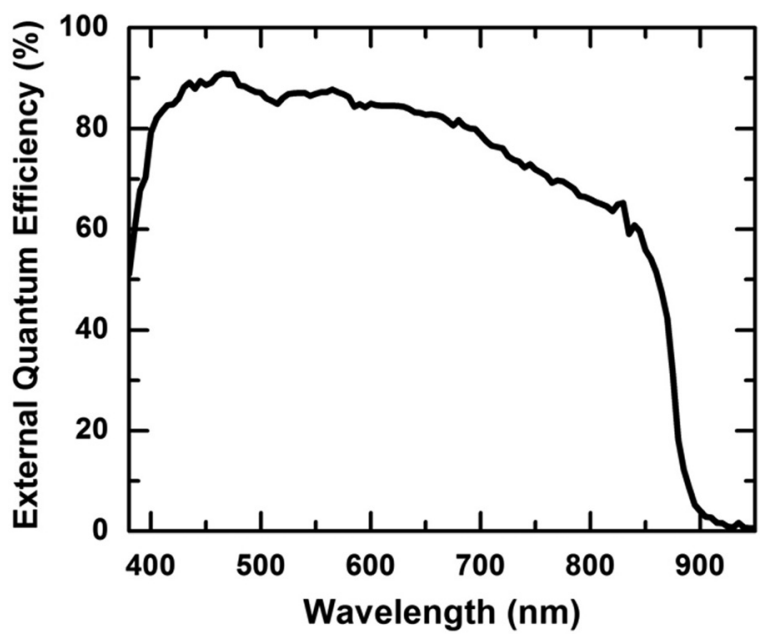

FIG. 9. External quantum efficiency as a function of wavelength for the GaAs solar cell. 
$800 \mathrm{~nm}$ indicates that the textured back scattering has resulted in an increase in the EQE at these wavelengths. No interference fringes in the EQE spectrum between $550 \mathrm{~nm}$ and $870 \mathrm{~nm}$ are observed, indicating that the textured $\mathrm{Al}_{0.52} \mathrm{In}_{0.48} \mathrm{P}$ surface offers reasonably effective light scattering. ${ }^{17}$ However, the presence of a lower EQE at the longer wavelengths compared to that at the shorter wavelengths indicates that the reflective back scattering is not as efficient as Lambertian scattering/reflection.

\section{CONCLUSION}

Semi-analytical modeling shows that one of the highest potential efficiencies for GaAs single-junction solar cells with conventional material quality can be obtained through the combination of an ultra-thin absorber and a reflective back scattering layer. Ultra-thin, double-heterostructural, single-junction $\mathrm{In}_{0.49} \mathrm{Ga}_{0.51} \mathrm{P} / \mathrm{GaAs} / \mathrm{In}_{0.49} \mathrm{Ga}_{0.51} \mathrm{P}$ solar cells, monolithically integrated with a lattice-matched textured $\mathrm{Al}_{0.52} \mathrm{In}_{0.48} \mathrm{P}$ layer coated with a $\mathrm{Au}$ mirror have been successfully demonstrated. Open-circuit voltages up to $1.00 \mathrm{~V}$, short-circuit current densities up to $24.5 \mathrm{~mA} / \mathrm{cm}^{2}$, and a maximum power conversion efficiency of $19.1 \%$ are measured under 1 sun AM 1.5G solar radiation. These results were obtained for substrate-removed and flip-chip bonded devices with an ultra-thin $300 \mathrm{~nm}$ GaAs absorber, a textured $\mathrm{Al}_{0.52} \mathrm{In}_{0.48} \mathrm{P}$ surface, a $\mathrm{MgF}_{2} / \mathrm{ZnS}$ AR coating, and a contact grid layout covering $9.7 \%$ of the front surface area. If a more conventional $2 \%$ metal grid shadow is assumed, a $J_{s c}$ of $26.6 \mathrm{~mA} / \mathrm{cm}^{2}$ and a conversion efficiency of $20.7 \%$ can be expected for these devices. Deviations in device performance from the ideal model are discussed. These initial results demonstrate the feasibility and potential of using an ultra-thin GaAs single-junction solar cell design integrated with a reflective back scattering layer to optimize light management and minimize non-radiative recombination.

\section{ACKNOWLEDGMENTS}

We thank C. Allen, A. P. Kirk, D. Ding, and Y. Zhao for their helpful comments and stimulating discussions. We gratefully acknowledge the use of facilities within the Center for Solid State Science as well as the Center for Solid State Electronics Research at Arizona State University. This work was supported in part by the Science Foundation Arizona,
Contract No. SRG 0339-08, and NSF grant Contract No. 1002114.

${ }^{1}$ M. A. Green, K. Emery, Y. Hishikawa, W. Warta, and E. D. Dunlop, Prog. Photovoltaics 21, 827 (2013).

${ }^{2}$ G. J. Bauhuis, P. Mulder, E. J. Haverkamp, J. C. C. M. Uijben, and J. J. Schermer, Sol. Energy Mater. Sol. Cell 93, 1488 (2009).

${ }^{3}$ B. M. Kayes, H. Nie, R. Twist, S. G. Spruytte, F. Reinhardt, I. C. Kizilalli, and G. S. Higashi, in Proceedings of 37th Photovoltaic Specialists Conference (IEEE, Seattle, WA, 2011), p. 4.

${ }^{4}$ M. A. Steiner, J. F. Geisz, I. Garcia, D. J. Friedman, A. Duda, and S. R. Kurtz, J. Appl. Phys. 113, 123109 (2013).

${ }^{5}$ D. Ding, S. R. Johnson, and Y.-H. Zhang, in Proceedings of 35th Photovoltaic Specialists Conference (IEEE, Honolulu, HI, 2010), p. 2908.

${ }^{6}$ D. Ding, S. R. Johnson, S.-Q. Yu, S.-N. Wu, and Y.-H. Zhang, J. Appl. Phys. 110, 123104 (2011).

${ }^{7}$ O. D. Miller, E. Yablonovitch, and S. R. Kurtz, IEEE J. Photovoltaics 2 , 303 (2012).

${ }^{8}$ E. D. Kosten, J. H. Atwater, J. Parsons, A. Polman, and H. A. Atwater, Light: Sci. Appl. 2, e45 (2013).

${ }^{9}$ X. Wang, M. R. Khan, J. L. Gray, A. Alam, and M. S. Lundstrom, IEEE J. Photovoltaics 3, 737 (2013).

${ }^{10} \mathrm{G}$. Lush and M. Lundstrom, Sol. Cells 30, 337 (1991).

${ }^{11}$ J. J. Schermer, G. J. Bauhuis, P. Mulder, E. J. Haverkamp, J. van Deelen, A. T. J. van Niftrik, and P. K. Larsen, Thin Solid Films 511-512, 645 (2006).

${ }^{12}$ E. Yablonovitch and G. D. Cody, IEEE Trans. Electron Devices ED-29, 300 (1982).

${ }^{13}$ M. Boroditsky, R. Ragan, and E. Yablonovitch, Sol. Energy Mater. Sol. Cells 57, 1 (1999).

${ }^{14}$ D. Liang, Y. Kang, Y. Huo, Y. Chen, Y. Cui, and J. Harries, Nano Lett. 13, 4850 (2013).

${ }^{15}$ S. Liu, D. Ding, S. R. Johnson, and Y.-H. Zhang, Proc. SPIE 8256 , $82560 \mathrm{M}(2012)$.

${ }^{16} \mathrm{~S}$. Liu, D. Ding, S. R. Johnson, and Y.-H. Zhang, in Proceedings of 38th Photovoltaic Specialists Conference (IEEE, Austin, TX, 2012), p. 002082.

${ }^{17}$ W. Yang, C. Allen, J.-J. Li, H. Cotal, C. Fetzer, S. Liu, D. Ding, S. Farrell, Z. He, H. Li, H. Dettlaff, N. Karam, and Y.-H. Zhang, in Proceedings of 38th Photovoltaic Specialists Conference (IEEE, Austin, TX, 2012), p. 000978.

${ }^{18}$ W. Yang, J. Becker, Y.-S. Kuo, J.-J. Li, S. Liu, B. Landini, K. Campman, and Y.-H. Zhang, in Proceedings of 39th Photovoltaic Specialists Conference (IEEE, Tampa, FL, 2013), p. 003329.

${ }^{19}$ E. D. Palik, Handbook of Optical Constants of Solids (Academic, New York, 1985)

${ }^{20}$ S. Adachi, Optical Constants of Crystalline and Amorphous Semiconductors: Numerical Data and Graphical Information (Kluwer Academic Publishers, Massachusetts, 1999).

${ }^{21}$ D. E. Aspnes, S. M. Kelso, R. A. Logan, and R. Bhat, J. Appl. Phys. 60, 754 (1986).

${ }^{22}$ S. Adachi, J. Appl. Phys. 58, R1 (1985).

${ }^{23}$ B. T. Phong, Commun. ACM 18, 311-318 (1975).

${ }^{24}$ S. Liu, J. Becker, S. Farrell, W. Yang, and Y.-H. Zhang, in Proceedings of 39th Photovoltaic Specialists Conference (IEEE, Tampa, FL, 2013), p. 002105 . 